\title{
SOME RECENT STUDIES ON THE METABOLITES OF FUNGI AND LICHENS
}

\author{
S. SHIBATA \\ Faculty of Pharmaceutical Sciences, University of Tokyo, Hongo, Tokyo, Japan
}

\begin{abstract}
Various anthraquinonoid colouring matters grouped into (a) monomeric anthraquinones, (b) bianthraquinones and (c) modified bianthraquinones were isolated from Penicillium islandicum, $P$. rugulosum, and other fungi. The unusual cagelike structures of hepatotoxic luteoskyrin, (-)rubroskyrin, $(+)$ rugulosin and their analogues are elucidated. The absolute stereochemical structures of these fungal colouring matters have been established on the basis of the $\mathrm{x}$-ray crystallographical analysis of a bromination product of $(+)$ tetrahydrorugulosin. The photoreaction of $(-)$ luteoskyrin is discussed in elucidatirg the structure of the product, lumiluteoskyrin. In addition, $(-)$ flavoskyrin, isolated from a strain of Penicillium islandicum, has now been proved to be a modified bianthraquinone. An unusual dimerization reaction of the dihydroanthraquinones which were synthesized as model compounds for flavoskyrin is also discussed. (+)Rugulosin, skyrin, some fungal modified bixanthones and their related compounds have recently been found in certain lichens. The biogenetical correlation between the metabolites of fungi and lichens is discussed in the light of studies on the secondary metabolism of lichen mycobionts.
\end{abstract}

\section{INTRODUCTION}

During the past several years, my co-workers and I have been much concerned with the problems of the anthraquinonoid colouring matters produced by Pencillium islandicum Sopp, $P$. rugulosum Thom and some other related fungi ${ }^{1,2}$. Until now more than twenty anthraquinoids have been isolated from these fungi, which are grouped into (a) monomeric anthraquinones, (b) bianthraquinones and (c) modified bianthraquinones ${ }^{1-4}$.

The modified bianthraquinones, luteoskyrin, rubroskyrin and rugulosin, are not only remarkable with their peculiar chemical structures but also notable with respect to their biological activities as mycotoxins. The hepatotoxicity of luteoskyrin of Pencillium islandicum which can cause liver cirrhosis and sometimes liver carcinoma in long term feeding experiments on mice and rats drew general attention, because the mould producing this compound has been found polluting some foodstuffs such as stored rice grains ${ }^{5-7}$. This happened in our country a few years before aflatoxin was reported as the factor of Turkey-X disease in England ${ }^{8,9}$. Various toxicological and biochemical investigations have been carried out by some workers who found that (-)-luteoskyrin impairs the mitochondrial function and binds with DNA 
at the site of pyrimidine bases in the presence of magnesium ion to inhibit the synthesis of nuclear RNA by the modification of DNA-dependent RNA-polymerase ${ }^{10-13}$. The toxic effects of $(+)$ rugulosin have also been studied extensively by Ueno and his collaborators ${ }^{14}$ to show a similar but less toxic effect in comparison with (-)luteoskyrin, while (-)rugulosin has been found to have a weaker activity than the $(+)$ isomer.

In the earlier stages of our investigation on these fungal metabolites, we proposed to represent the structures of $(-)$ luteoskyrin, $(-)$ rubroskyrin and $(+)$ rugulosin as formulated at (I), (II) and (I'), respectively; these were mainly based on their chemical reactions and i.r. spectral data ${ }^{15,16}$.

(-)Luteoskyrin, $\mathrm{C}_{30} \mathrm{H}_{22} \mathrm{O}_{12}$, yellow crystals m.pt $281^{\circ}$ (decomp.), $[\alpha]_{D}$ $-880^{\circ}$ (dioxan). (-)Rubroskyrin, $\mathrm{C}_{30} \mathrm{H}_{22} \mathrm{O}_{12}$, deep red crystals, m.pt $181^{\circ}$. (decomp.). From Pencillium islandicum Sopp NRRL 1036, U and E strains. $(+)$ Rugulosin, $\mathrm{C}_{30} \mathrm{H}_{22} \mathrm{O}_{10}$, yellow crystals, m.pt $290^{\circ}$ (decomp.), $[\alpha]_{D}+492^{\circ}$ (dioxan). From Pencillium rugulosum Thom, $P$. wortmanni Klöcker, $P$. tardum Thom, P. brunneum Udagawa, Endothia parasitica (Müll.) Anders. et Anders., E. fluens Shear et Stevens, Sepedonium ampullosporum Damon, P. variabile Sopp.

Table 1. The i.r. spectral absorption of $(+)$ rugulosin, $(-)$ luteoskyrin, $(-)$ rubroskyrin and their acetates, $\mathrm{cm}^{-1}$

\begin{tabular}{|c|c|c|c|c|c|}
\hline & \multicolumn{2}{|c|}{ Ketone $\mathrm{C}=\mathrm{O}$} & \multicolumn{2}{|c|}{ Acetate $\mathrm{C}=\mathrm{O}$} & \multirow[t]{2}{*}{$\mathrm{OH}$} \\
\hline & Non-chelated & Chelated & Alcoholic & $\begin{array}{l}\text { Phenolic or } \\
\text { enolic }\end{array}$ & \\
\hline Rugulosin & 1690 & 1620 & - & - & 3360 \\
\hline Diacetate & 1690 & 1620 & 1754 & - & - \\
\hline Hexaacetate & 1690 & - & 1751 & 1773 & - \\
\hline Luteoskyrin & - & 1623 & - & - & 3378 \\
\hline Octaacetate & 1707 & - & 1751 & 1774 & (Dioxan*) \\
\hline Rubroskyrin & 1697. & 1623 & - & - & $\begin{array}{l}3559(w) \\
3341(\mathrm{~s})\end{array}$ \\
\hline Diacetate & 1708 & 1620 & 1749 & - & $-(\mathrm{KBr})^{*}$ \\
\hline Triacetate & 1705 & 1645 & 1745 & 1770 & $\ldots$ \\
\hline
\end{tabular}

* Unless otherwise stated the i.r. spectra were measured in Nujol.

The completely aromatic bianthraquinones occurring in Pencillium islandicum as well as those derived from $(-)$ luteoskyrin, (-)rubroskyrin and $(+)$ rugulosin by dehydration reactions show optical activity caused by the atropisomerism ${ }^{17}$. (+)Iridoskyrin (III) naturally occurring or derived from $(-)$ luteoskyrin and $(-)$ rubroskyrin shows an opposite chirality about the $\mathrm{C}-\mathrm{C}$ linkage with that of $\left(-\right.$ )dianhydrorugulosin $\left(\mathrm{III}^{\prime}\right)$ derived from $(+)$ rugulosin. This has been demonstrated by means of the ORD measurements.

\section{(-)LUTEOSKYRIN, (-)RUBROSKYRIN AND (+)RUGULOSIN THE RENEWED INVESTIGATIONS}

It has been found by renewed examination of the structures of $(+)$ rugulosin and ( - )luteoskyrin using n.m.r. spectrometry that the structural formulae (I) and $\left(I^{\prime}\right)$ formerly proposed are inconsistent with the n.m.r. spectral data which 
STUDIES ON THE METABOLITES OF FUNGI AND LICHENS

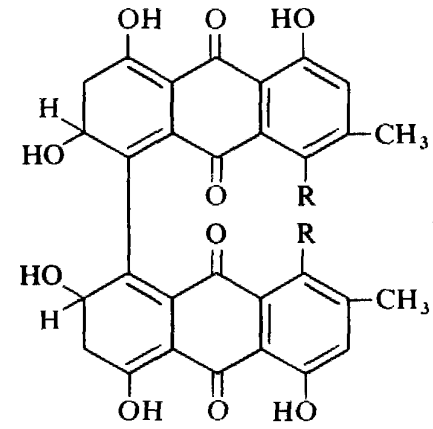

(I) $\mathrm{R}=\mathrm{OH}(-)$ Luteoskyrin

(I') $\mathbf{R}=\mathbf{H}^{\prime}(+)$ Rugulosin<smiles>Cc1cc(O)c2c(c1O)C(=O)C1=C(C2=O)C(C2C3=C(C(=O)CC2O)C(=O)c2c(O)cc(C)c(O)c2C3=O)C(O)CC1=O</smiles>

(II) (-)Rubroskyrin

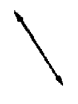<smiles>[R]c1c(C)cc(O)c2c1C(=O)c1c(-c3c([R])c4c(=O)c5c(O)ccc(O)c5c(=O)c=4c3=O)ccc(O)c1C2=O</smiles>

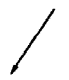

(III) $\mathrm{R}=\mathrm{OH}(+)$ Iridoskyrin

(III') $\mathrm{R}=\mathrm{H}(-)$ Dianhydrorugulosin

show no evidence for the presence of the structural system $=\mathrm{C}-\mathrm{CH}_{2}-\mathrm{CH}-$ $(\mathrm{OH})$ - in the hydrogenated ring portion. On the other hand, a characteristic pattern of the n.m.r. spectrum involving the three distinct signals, a, b and c, in the region of $\delta 2 \sim 5$ p.p.m., was given by $(-)$ luteoskyrin and $(+)$ rugulosin.

$(+)$ Tetrahydrorugulosin which was prepared by hydrogenation of $(+)$ rugulosin gave no i.r. absorption of non-chelated $\mathrm{C}=\mathrm{O}$ and exhibited a n.m.r. spectrum involving a remarkable high field shift of the signal (b) and the appearance of a signal of secondary alcohol $[\delta 4.70(\mathrm{H})$ and $\delta 6.24(\mathrm{OH})]$. The peracetate of tetrahydrorugulosin revealed a down field shift of the signal of the proton attached to the carbon atom bearing the newly formed secondary alcoholic hydroxyl (a sharp singlet at $\delta 6.21$ p.p.m.). This indicates the presence of a quaternary carbon atom close to the secondary alcohol (originally the non-chelated $\mathrm{C}=\mathrm{O}$ ) at the 9 and $9^{\prime}$ positions.

The n.m.r. spectral evidence mentioned above reveals the presence of a structural system

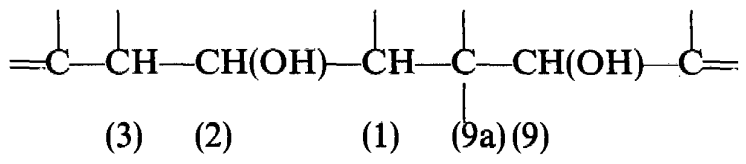


in $(+)$ tetrahydrorugulosin and a corresponding system

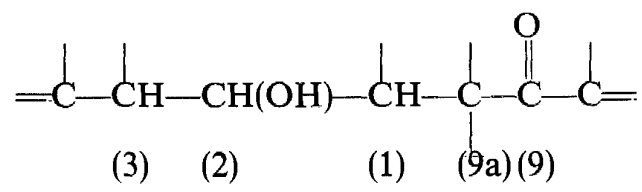

in $(+)$ rugulosin. The same correlations are shown in the n.m.r. spectra of $(-)$ tetrahydroluteoskyrin and $(-)$ luteoskyrin.
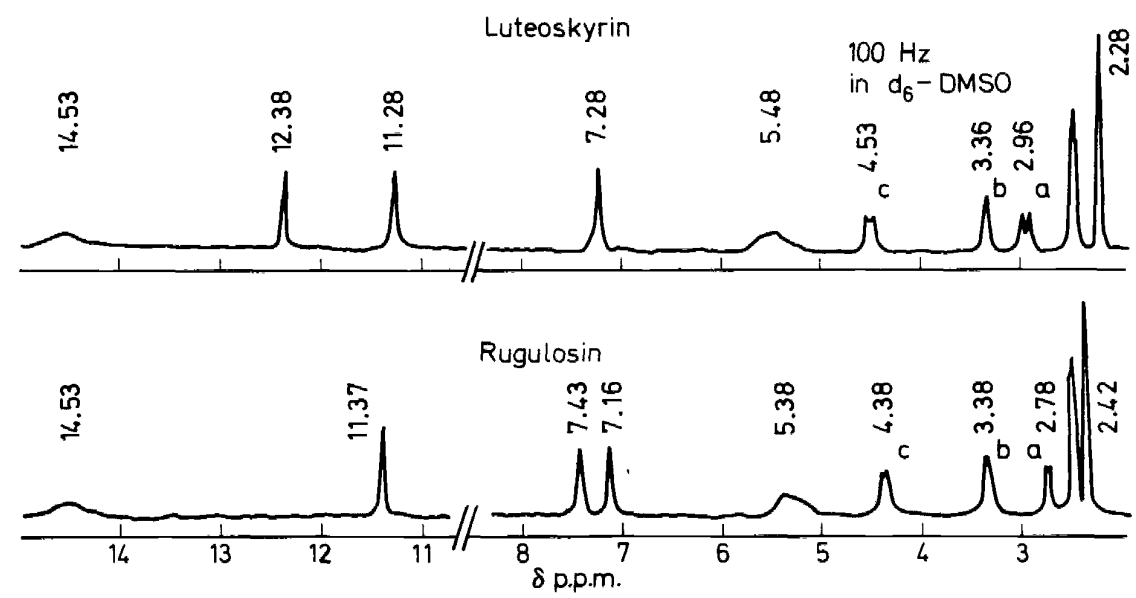

Figure 1. The n.m.r. spectra (in $\mathrm{d}_{6}$-DMSO) of (-)-luteoskyrin and (+)-rugulosin.

The higher shift of the n.m.r. signal (b) which is now assigned to the proton at $C\left(1,1^{\prime}\right)$ must have resulted from the conversion of $C=O$ at $C\left(9,9^{\prime}\right)$ into secondary alcohol on reduction. Thus the partial structures of $(-)$ luteoskyrin and $(+)$ rugulosin can be illustrated as follows:<smiles>[R]c1c(C)cc(O)c2c1C(=O)[C@@]1(C)C(=C(O)[C@H](C)[C@H](O)[C@H]1C)C2=O</smiles>

$\mathbf{R}=\mathbf{H}$, rugulosin $\mathrm{R}=\mathrm{OH}$, luteoskyrin

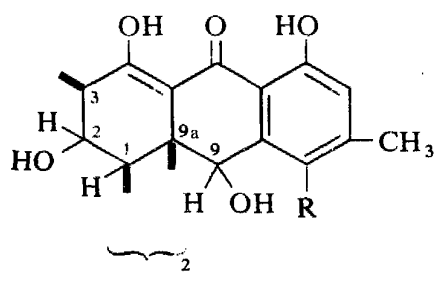

$\mathrm{R}=\mathrm{H}$, tetrahydrorugulosin

$\mathrm{R}=\mathrm{OH}$, tetrahydroluteoskyrin

The monomeric halves of these compounds are linked to each other at $\mathrm{C}(1)$ and $C\left(1^{\prime}\right)$, while $C(9 a), C\left(9^{\prime} a\right), C(3)$ and $C\left(3^{\prime}\right)$ must be occupied by $C-C$ linkages. If the other two linkages are present between $C(3)$ and $C\left(9^{\prime} a\right)$ as well as between $C\left(3^{\prime}\right)$ and $C(9 a),(-)$ luteoskyrin and $(+)$ rugulosin can be formulated as (IV) and (VI), respectively ${ }^{18,19}$. Based on these structures, the n.m.r. 
spectral signals $a, b$ and $c$ are assigned to the protons at $C\left(3,3^{\prime}\right), C\left(1,1^{\prime}\right)$ and $\mathrm{C}\left(2,2^{\prime}\right)$, respectively, whose stereochemical correlations are proved by the decoupling process : $\mathrm{a} \leftrightarrow \mathrm{c}(J=5.5 \mathrm{~Hz}) ; \mathrm{b} \leftrightarrow \mathrm{c}(J=1 \sim 2 \mathrm{~Hz})$. The dihedral angle between $\mathrm{H}(1)$ and $\mathrm{H}(2 \mathrm{eq})$ is about $60^{\circ}$, and the coupling constant calculated from the Karplus equation is about $2 \mathrm{~Hz}$; the dihedral angle between $\mathrm{H}(2)$ and $\mathrm{H}(3)$ is about $40^{\circ}$ and the coupling constant is about $6 \mathrm{~Hz}$. The $\mathrm{H}(1)$ and $\mathrm{H}(3)$ are located on a 5-membered ring with an equatorial conformation affecting each other by a long range coupling to result in a broad singlet of the signal $b$. It has been known for some time that (-)rubroskyrin, a deep red coloured quinonic pigment, is readily transformed into (-)luteoskyrin, a non-quinonic yellow pigment, by the action of pyridine. So the n.m.r. spectrum of $(-)$ rubroskyrin was examined in relation to the revised structure of $(-)$ luteoskyrin.

$(-)$ Rubroskyrin triacetate prepared from $(-)$ rubroskyrin with acetic anhydride and $p$-toluenesulphonic acid at room temperature showed a pair of doublets with a large coupling constant $(J=17.5 \mathrm{~Hz})$ in the higher field of its n.m.r. spectrum to indicate the presence of a methylene in the hydrogenated ring portion. The coupling of the n.m.r. spectrum $(e \leftrightarrow f, d \leftrightarrow a$, $\mathrm{d} \leftrightarrow \mathrm{c}$ and $\mathrm{c} \leftrightarrow \mathrm{b})$ revealed the structural system shown in the dimeric molecule.

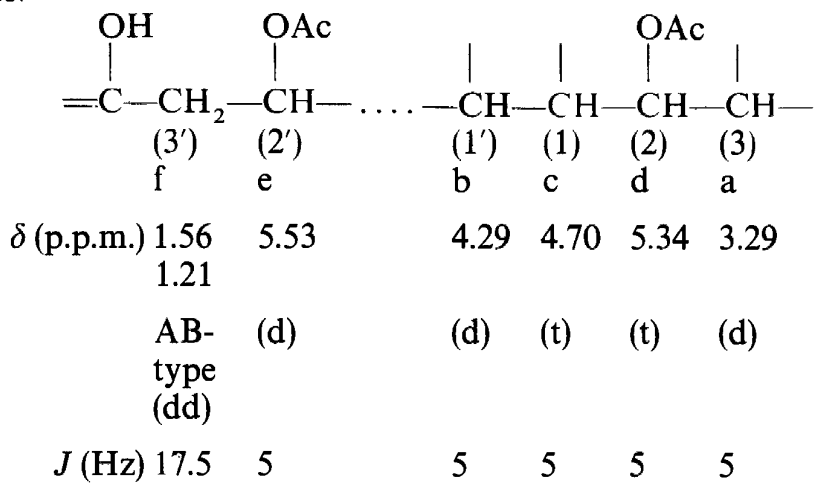

The dihedral angle between $\mathrm{H}\left(1^{\prime}\right)$ and $\mathrm{H}\left(2^{\prime}\right)$ is about $90^{\circ}$ giving no coupling pattern, while those between $H(1)$ and $H\left(1^{\prime}\right), H(1)$ and $H(2)$ and $H(2)$ and $H(3)$ are approximately $30^{\circ}$ to $40^{\circ}$ giving coupling constants of about $5 \mathrm{~Hz}$. Hence the structural formula of $\left(-\right.$ )rubroskyrin is considered to be $(V)^{19}$.

By analogy with the findings of Scheuer et al. ${ }^{20,21}$ in the n.m.r. spectra of alkylnaphthazarin derivatives which exhibit the signal of a proton on the quinone ring at higher field than the benzenoid protons, the proton signals of. (-)rubroskyrin at $\delta 6.80$ p.p.m. and 7.15 p.p.m. should be assigned respectively to the quinonoid and benzenoid protons. The former proton showed a weak coupling with the methyl signal at $\delta 2.20$ p.p.m.

The revised structures of (-)luteoskyrin (IV), (-)rubroskyrin (V) and (+)rugulosin (VI) look very unusual in appearance, but the cagelike structure connecting two monomeric moieties with three $\mathrm{C}-\mathrm{C}$ linkages could be set up with the Dreiding model without any strain. These structures can also be rationalized biogenetically when a hypothetical intermediate (VII) is subjected to the intramolecular Michael-type reaction. 
S. SHIBATA

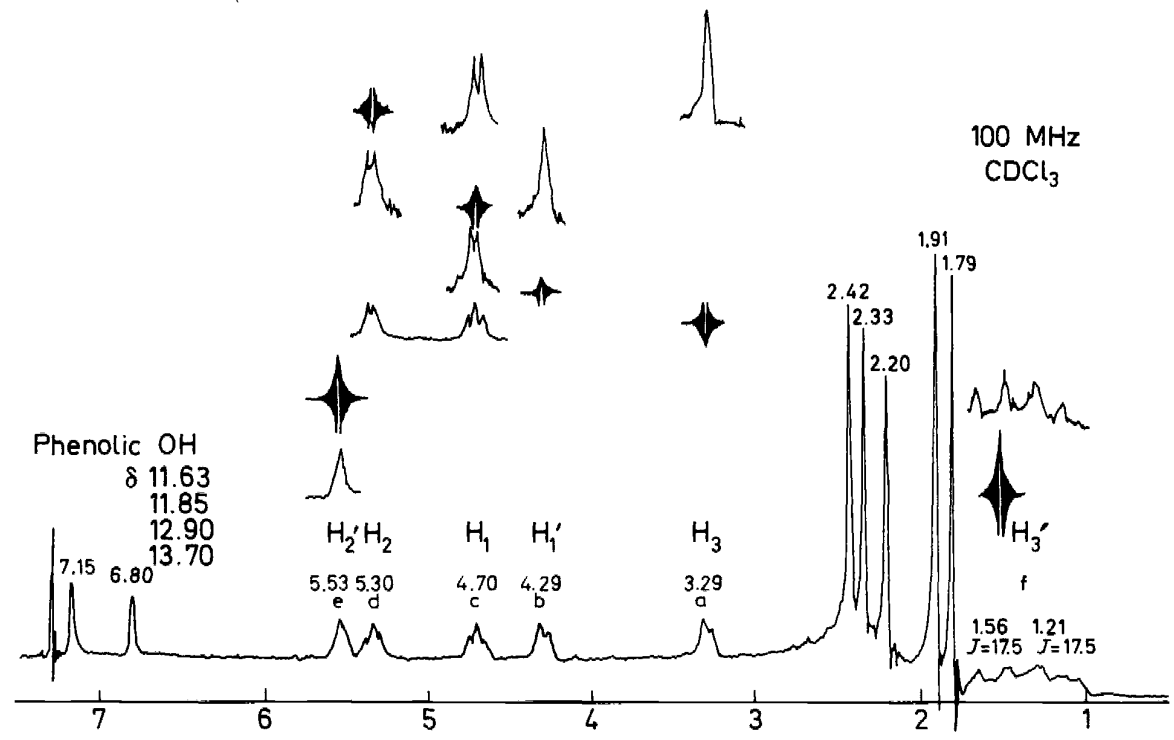

Figure 2. The n.m.r. spectrum of (-)-rubroskyrin triacetate (in $\mathrm{CDCl}_{3}$ ).

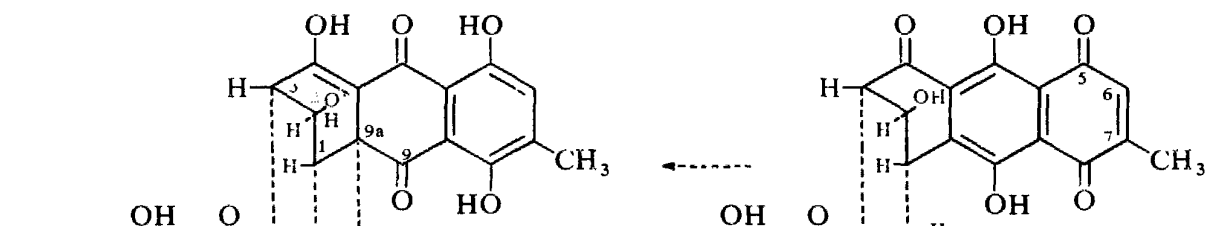<smiles>Cc1cc(O)c2c(c1O)C(=O)C(I)(I)C(I)(I)C2C(O)I</smiles>

(IV), (-)luteoskyrin<smiles>Cc1cc(O)c2c(c1O)C(=O)C1(I)C(=C2O)C(=O)[C@H]2COC1[C@H]2O</smiles>

(V), (-)rubroskyrin

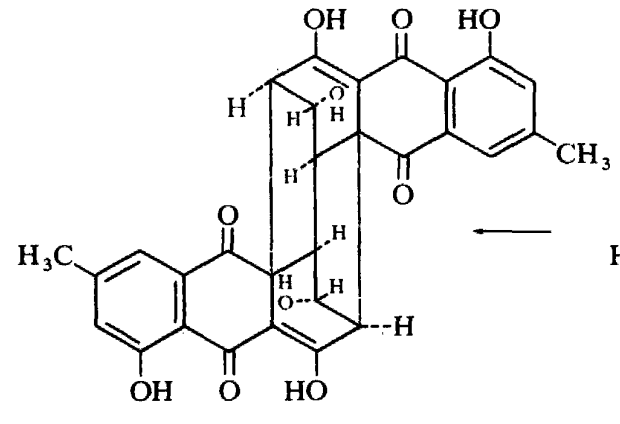

(VI), (+)rugulosin

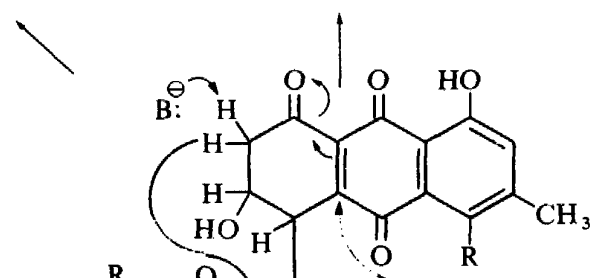

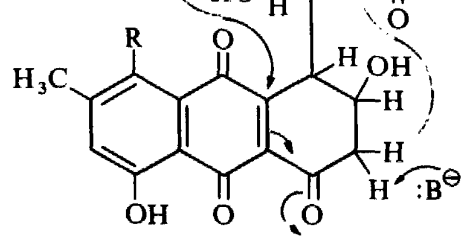

(VII) 


\section{(-)DEOXYLUTEOSKYRIN AND (-)DEOXYRUBROSKYRIN}

Recently we have isolated analogous compounds of $(-)$ luteoskyrin and (-)rubroskyrin from Pencillium islandicum Sopp NRRL 1036 ${ }^{22}$. (-)Deoxyluteoskyrin, $\mathrm{C}_{30} \mathrm{H}_{22} \mathrm{O}_{11}$, yellow crystals, m.pt $290^{\circ},[\alpha]_{\mathrm{D}}-610^{\circ}$ (dioxan), shows the i.r. absorptions of a chelated $\left(1625 \mathrm{~cm}^{-1}\right)$ and a nonchelated $\mathrm{C}=\mathrm{O}\left(1690 \mathrm{~cm}^{-1}\right)$ and yields roseoskyrin, a dimeric anthraquinone consisting of islandicin and chrysophanol.(-)Deoxyrubroskyrin, $\mathrm{C}_{30} \mathrm{H}_{22} \mathrm{O}_{11}$, red crystals, m.pt $255^{\circ}$, gives a blue colouration with magnesium acetate in contrast to the green colouration given by $(-$ )rubroskyrin; and it shows the i.r. absorptions of 1690 and $1670 \mathrm{~cm}^{-1}$ (non-chelated $\mathrm{C}=\mathrm{O}$ ), and $1618 \mathrm{~cm}^{-1}$ (chelated $\mathrm{C}=\mathrm{O}$ ). It is readily converted into $(-$ deoxyluteoskyrin by the action of pyridine under the same conditions which transform (-)rubroskyrin into $(-)$ luteoskyrin.

The n.m.r. spectral pattern of $(-)$ deoxyluteoskyrin is superimposable with the combination of those of $(-)$ luteoskyrin and $(+)$ rugulosin indicating that $(-)$ deoxyluteoskyrin is a non-equivalent dimer consisting of the monomeric halves of luteoskyrin and rugulosin.

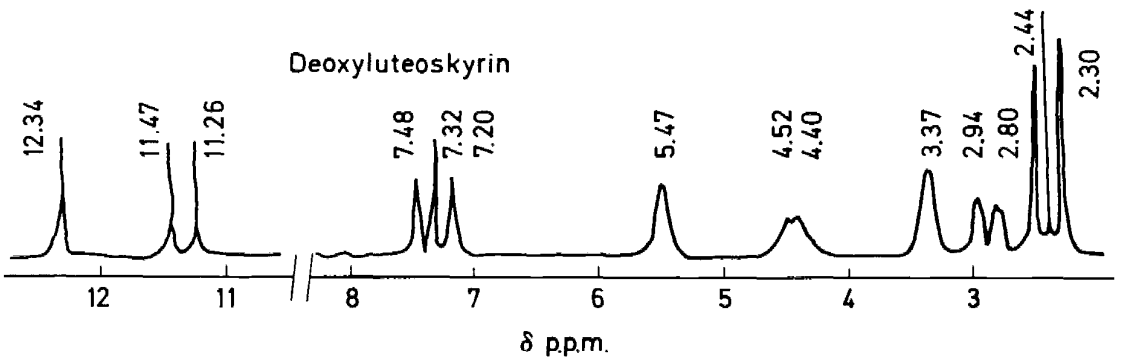

Figure 3. The n.m.r. spectrum (in $\mathrm{d}_{6}$-DMSO) of (-)-deoxyluteoskyrin.

( - )Deoxyrubroskyrin shows an u.v. spectral curve which consists of those of rubroskyrin and rugulosin indicating that a hydroxyl is not present at the $8^{\prime}$-position of the non-quinonic moiety.

By thermal decomposition as well as by electron impact, $(-)$ deoxyluteoskyrin $\left(M^{+} 558\right)$ gave one mole each of chrysophanol, emodin, islandicin and catenarin. This corresponds to the thermal decomposition and electron impact fragmentation of $(-)$ luteoskyrin $\left(M^{+}\right.$572) giving islandicin and catenarin and those of $(+)$ rugulosin giving chrysophanol and emodin.

\section{THE ABSOLUTE STEREOCHEMICAL STRUCTURES OF $(+)$ RUGULOSIN, (-)LUTEOSKYRIN AND (-)RUBROSKYRIN BASED ON THE X-RAY CRYSTALLOGRAPHY OF (+)DIBROMODEHYDROTETRAHYDRORUGULOSIN ${ }^{23,} 24$}

In order to establish the absolute stereochemical structure of $(+)$ rugulosin by $x$-ray crystallography using the heavy atom method, a bromo derivative of $(+)$ tetrahydrorugulosin was prepared; this formed a suitable single crystal 
S. SHIBATA

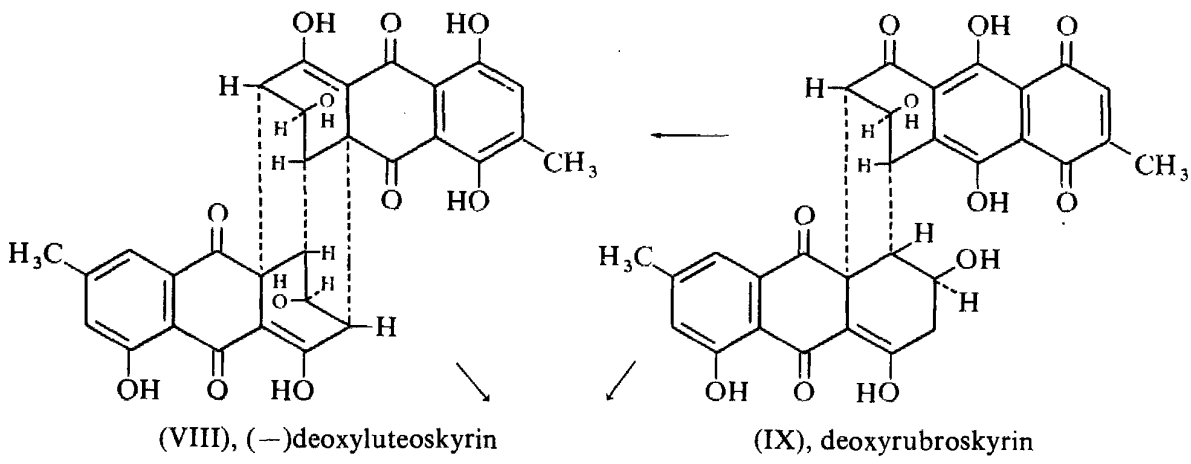

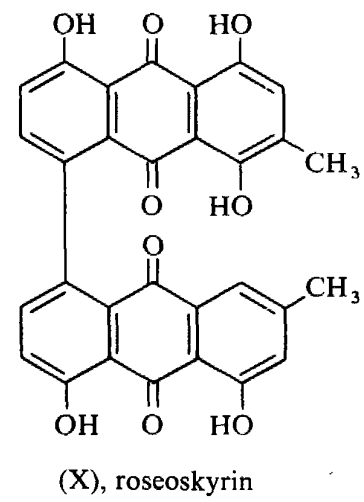

Table 2. Fragmentation of modified bianthraquinones

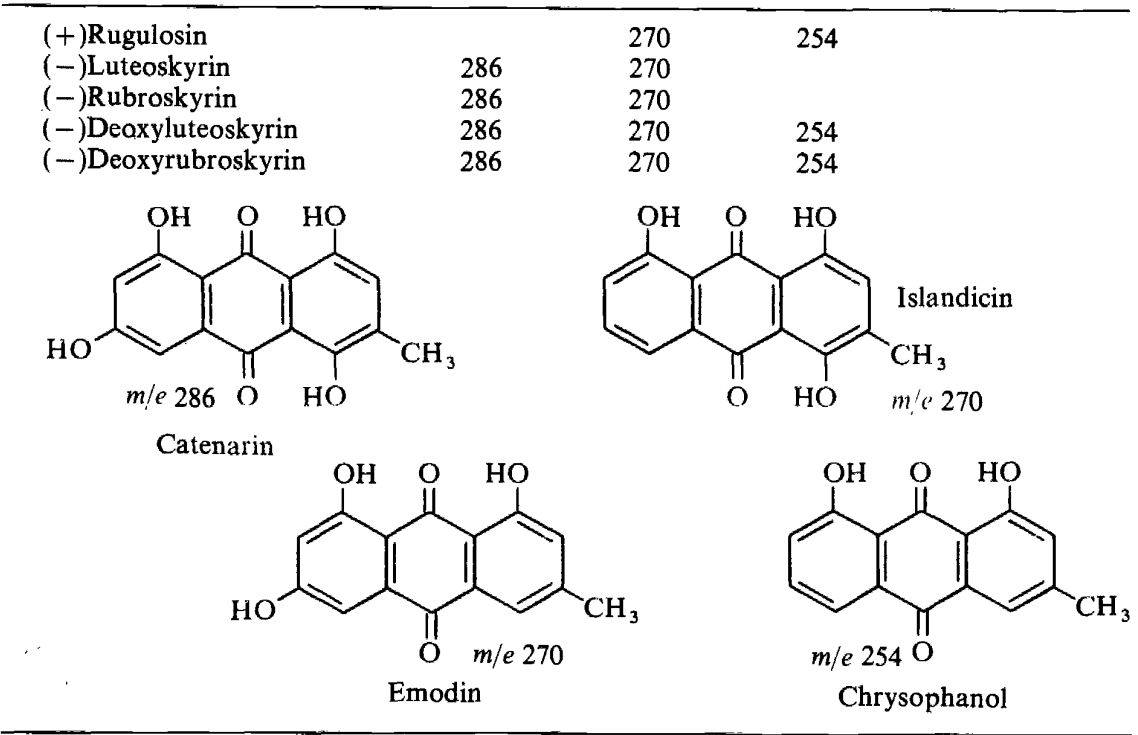


from a mixture of acetone, methanol and water. This compound has been proved to be $\left(+\right.$ dibromodehydrotetrahydrorugulosin, $\mathrm{C}_{30} \mathrm{H}_{22} \mathrm{O}_{10} \mathrm{Br}_{2}$, which was formed by dehydrogenation during the course of bromination with dioxandibromide in tetrahydrofuran. The n.m.r. signal of $\mathrm{C}\left(6,6^{\prime}\right)-\mathrm{H}(\delta 6.67$ p.p.m.) of tetrahydrorugulosin disappeared on bromination indicating that bromine was introduced to those positions. On bromination of tetrahydrorugulosin a lower shift of the n.m.r. signal of phenolic hydroxyl $(\Delta+1.05$ p.p.m.) and the conversion of the enolic hydroxyl into a ketone group which stands on a 5 -membered ring $\left(1755 \mathrm{~cm}^{-1}\right)$ were observed. Hence the dehydrogenation resulted in the fourth $\mathrm{C}-\mathrm{C}$ linkage between $4 \mathrm{a}$ and 4 'a to afford the product (XII).

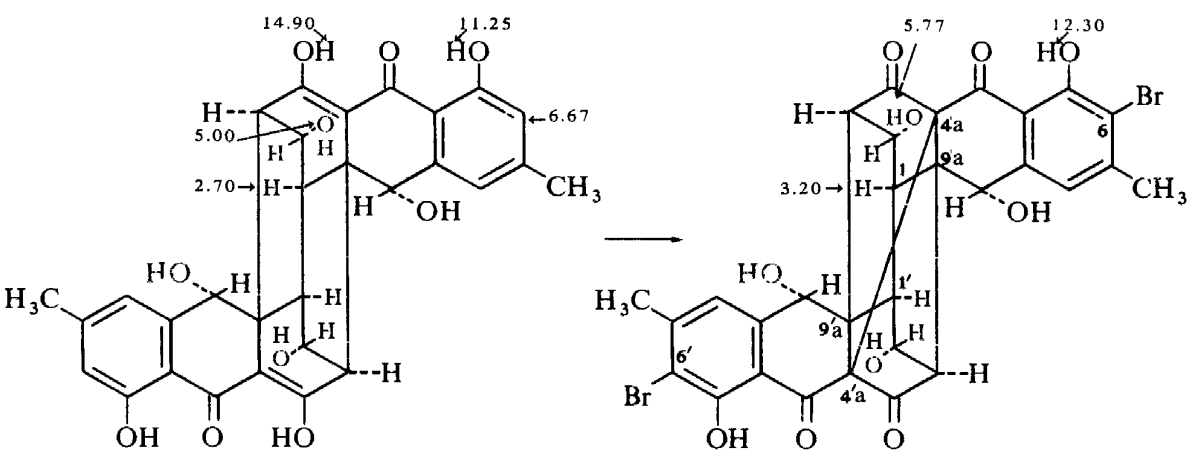

(XI), (+)tetrahydrorugulosin

(XII), (+)dibromodehydrotetrahydrorugulosin

The monoclinic crystal, $\mathrm{C}_{30} \mathrm{H}_{22} \mathrm{O}_{10} \mathrm{Br}_{2} \cdot \mathrm{H}_{2} \mathrm{O} \cdot 2 \mathrm{CH}_{3} \mathrm{OH}$, was measured with the precession photograph and Weissenberg photograph under $\mathrm{Cu}-\underline{\mathrm{K}}_{\mathrm{g}} \mathrm{x}$ radiation: $a=9.78 \pm 0.02, b=17.04 \pm 0.04, c=9.45 \pm 0.02 \AA ; \beta=98.0$ $\pm 0.2^{\circ} ; D_{x}=1.671 \mathrm{~g} / \mathrm{cm}^{-3}, D_{m}=1.684 \mathrm{~g} / \mathrm{cm}^{-3}\left(\mathrm{CH}_{2} \mathrm{Br}_{2} \cdot \mathrm{CHCl}_{3}\right)$; Space group: $P_{2_{1}}$; final $R$ value : 0.109 .

On the basis of the stereochemical structure of $(+)$ dibromodehydrotetrahydrorugulosin which was established by $\mathrm{x}$-ray crystallographic analysis, the absolute stereochemical structures of $(+)$ tetrahydrorugulosin, $(+)$ rugulosin, $(-)$ luteoskyrin and $(-)$ rubroskyrin and all their related derivatives have been formulated unequivocally.

\section{THE PHOTOREACTION OF (-)LUTEOSKYRIN}

One of the most characteristic properties of $(-)$ luteoskyrin is its photosensitivity in being converted into a deep coloured quinonic compound named lumiluteoskyrin ${ }^{25}$. Lumiluteoskyrin, $\mathrm{C}_{30} \mathrm{H}_{20} \mathrm{O}_{12}, \mathrm{~m} . \mathrm{pt}>370^{\circ}$, shows an u.v. absorption curve similar to that of quinone $B$ [ $\lambda_{\max } 495,530-$ (inflex), 570(inflex) nm] which was isolated by Bu'Lock and Smith $^{26}$ from a mutant of Penicillium islandicum. This suggested that the quinone B moiety is involved in the structure of lumiluteoskyrin.

The i.r. spectrum of lumiluteoskyrin $\left[1697 \mathrm{~cm}^{-1}\right.$ (non-chelated $\mathrm{C}=\mathrm{O}$ ) and $1608 \mathrm{~cm}^{-1}$ (chelated $\mathrm{C}=\mathrm{O}$ )] resembles that of rubroskyrin $\left[1697 \mathrm{~cm}^{-1}\right.$ (non-chelated $\mathrm{C}=\mathrm{O}$ ) and $1608 \mathrm{~cm}^{-1}$ (chelated $\left.\mathrm{C}=\mathrm{O}\right)$ ]. The n.m.r. spectrum 


\section{S. SHIBATA}<smiles>CC1=CC(=O)c2c(O)c3c(c(O)c2C1=O)C[C@H](O)CC3=O</smiles>

Quinone B (Bu'Lock et al.)

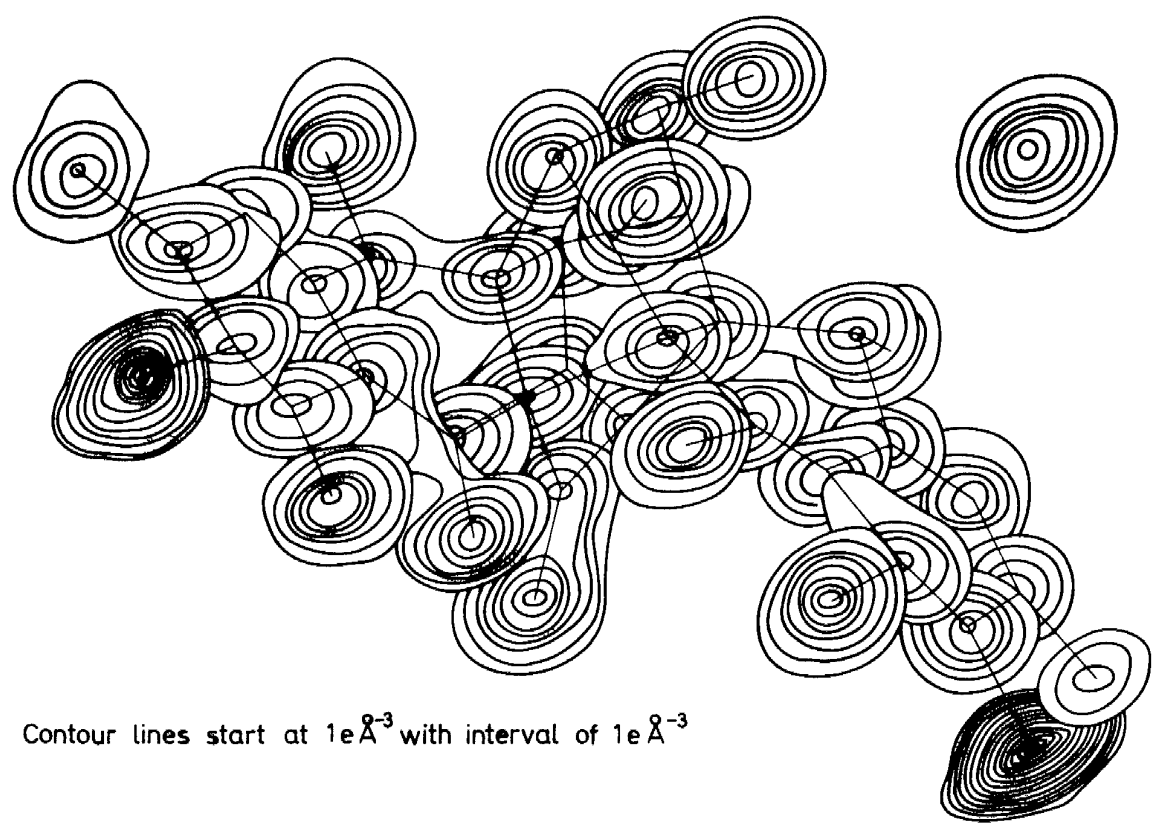

Figure 4. Composite drawing of the electron density map viewed along the $b$ axis. Contours are drawn for light atoms at intervals of $1 \mathrm{e} . \AA^{-3}$ and for bromine atoms at intervals of $2.5 \mathrm{e} . \AA^{-3}$ starting at $1 \mathrm{e} . \AA^{-3}$. Those for methanol molecules are not shown.

of lumiluteoskyrin tetraacetate, $\mathrm{C}_{30} \mathrm{H}_{16} \mathrm{O}_{8}\left(\mathrm{OCOCH}_{3}\right)_{4}$, m.pt $360^{\circ},[\alpha]_{\mathrm{D}}+$ $178^{\circ}$ (dioxan) and its decoupling pattern revealed the following structural system in the molecule:<smiles>CC(C)C(C)(C)C(C)C(=O)O</smiles>

$\delta$ (p.p.m.) $3.255 .23 \quad 4.45$

$$
\begin{aligned}
& J_{a c}=2.5 \mathrm{~Hz} \\
& J_{b c}=3 \mathrm{~Hz} \\
& J_{a b}=1 \mathrm{~Hz} \text { (long range coupling) }
\end{aligned}
$$



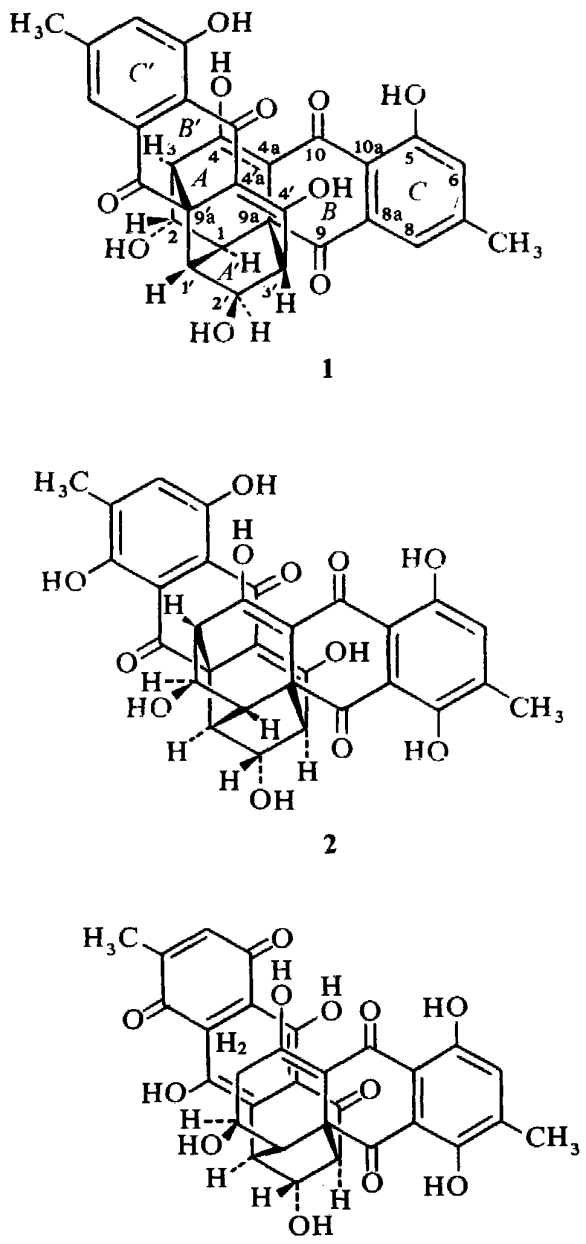

3

Figure 5. The chemical structures and the absolute configurations of $1,(+)$-rugulosin; $2,(-)-$ luteoskyrin; 3, (-)-rubroskyrin.

The n.m.r. signal at $\delta 6.79$ p.p.m. (d. $J=1 \mathrm{~Hz}$ ) showed the presence of a proton adjacent to a methyl on a quinone ring.

The structure (XIII) has been put forward to represent lumiluteoskyrin ${ }^{27}$, and the mechanism of photooxidation which is also shown by $(-)$ deoxyluteoskyrin (VIII) is illustrated below. As $(+)$ rugulosin which possesses no $p$-dihydroxyl system in the benzenoid portion of its molecule is stable against illumination by light, the photoreaction initiates at the $p$-diketones chelated with the $p$-diphenolic system in the molecules of luteoskyrin and deoxyluteoskyrin. The e.s.r. spectrum of $(-)$ luteoskyrin under illumination of light $(>350$ $\mathrm{nm})$ revealed the radical formation. 


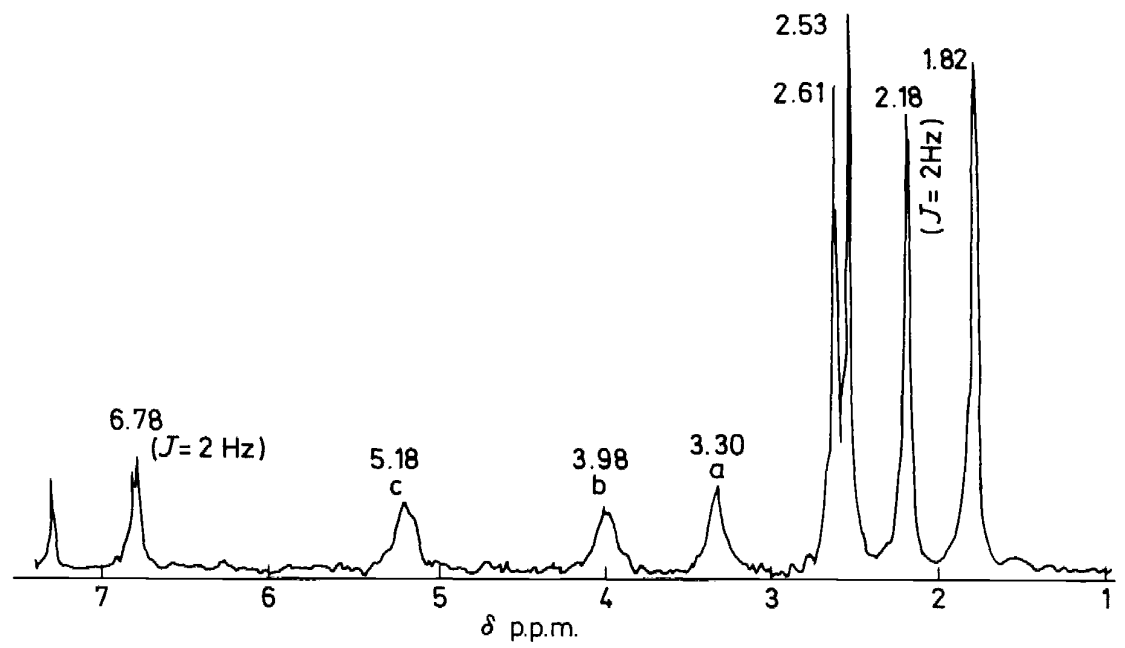

Figure 6. The n.m.r. spectrum (in $\mathrm{CDCl}_{3}$ ) of lumiluteoskyrin hexaacetate.

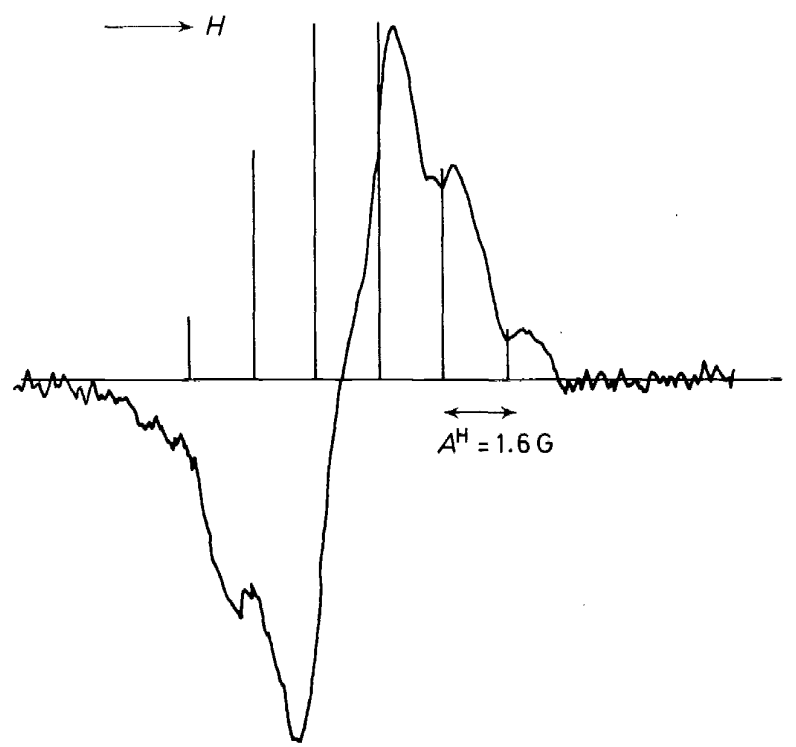

Figure 7. The e.s.r. spectrum of (-)-luteoskyrin under the illumination of light (>350 nm) in DMSO. 


\section{STUDIES ON THE METABOLITES OF FUNGI AND LICHENS}
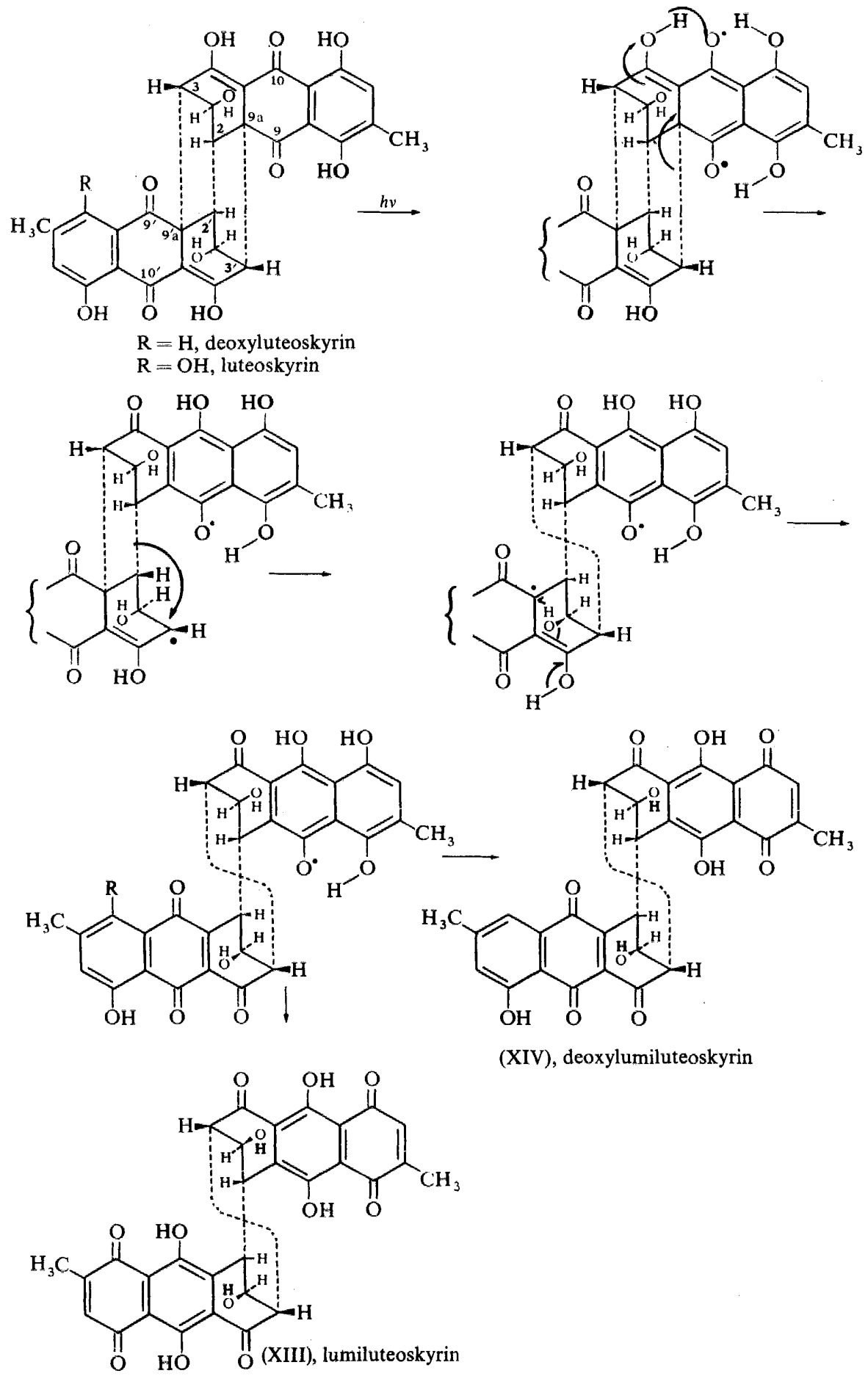


\section{(+)4a-OXYRUGULOSIN, (-)4a-OXYLUTEOSKYRIN,}

\section{$(+) 4 a, 4^{\prime}$ a-DIOXYRUGULOSIN, $(-) 4 a, 4^{\prime}$ a-DIOXYLUTEOSKYRIN AND (+)4a,4'a-DEHYDRORUGULOSIN ${ }^{28}$}

As a minor analogue of (-)luteoskyrin, (-)4a-oxyluteoskyrin, $\mathrm{C}_{30} \mathrm{H}_{22} \mathrm{O}_{13}$, yellow needles, $\mathrm{m} . \mathrm{pt}>250^{\circ}$ (decomp.), was isolated from Penicillium islandicum, while (+)4a-oxyrugulosin, $\mathrm{C}_{30} \mathrm{H}_{22} \mathrm{O}_{11}$, yellow rods, m.pt $>270^{\circ}$ (decomp.) was obtained from Penicillium brunneum. These compounds were prepared on oxidation with perfluoroacetic acid along with the $4 a, 4^{\prime} a$-dihydroxylated derivatives from $(-)$ luteoskyrin and $(+)$ rugulosin, respectively.

The n.m.r. spectral data agreed with the following structural formulae $(\mathrm{XV})$ and $(\mathrm{XVI})$ for $(+) 4 \mathrm{a}$-oxyrugulosin and (-)4a-oxyluteoskyrin, respectively:

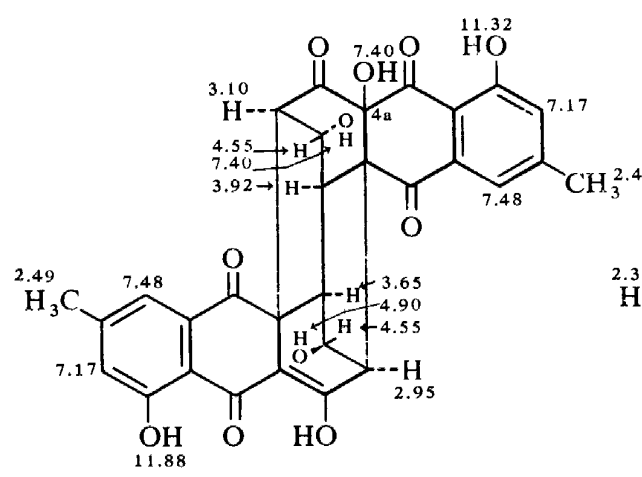

(XV), (+) 4a-oxyrugulosin

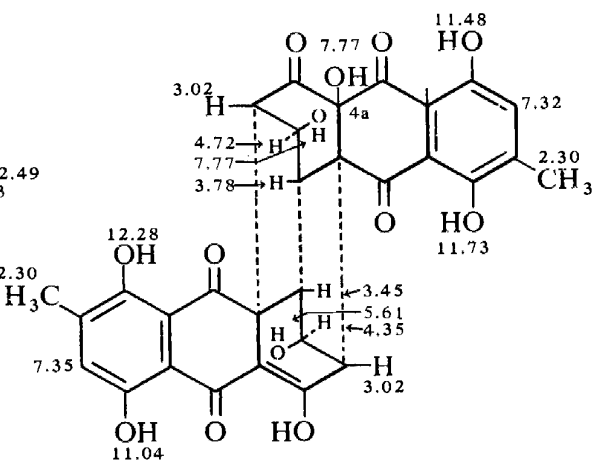

(XVI), (-) 4a-oxyluteoskyrin

The following structures are assigned to $(+) 4 \mathrm{a}, 4^{\prime} \mathrm{a}$-dioxyrugulosin $(\mathrm{XVII})$ and (-)4a,4'a-dioxyluteoskyrin (XVIII):

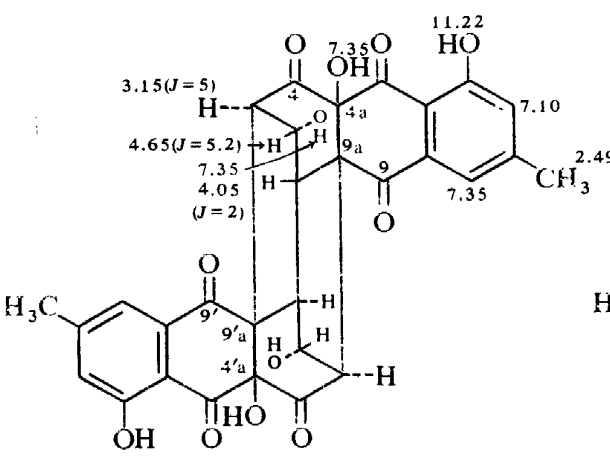

(XVII), 4a,4'a-dioxyrugulosin

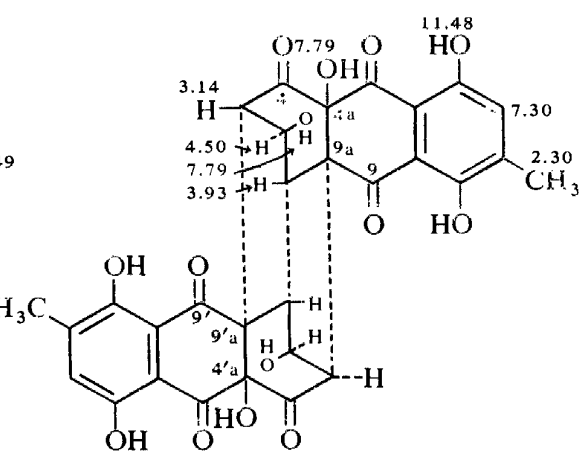

(XVIII), (-)4a,4'a-dioxyluteoskyrin 
On oxidation of $(+)$ rugulosin with activated manganese dioxide and sulphuric acid, (+)dehydrorugulosin, $\mathrm{C}_{30} \mathrm{H}_{18} \mathrm{O}_{10}$, m.pt $278^{\circ}$ (decomp.) was afforded. The diacetate of this compound gave a n.m.r. spectrum which agreed with the postulated structure (XIX) having an additional $\mathrm{C}-\mathrm{C}$ linkage between the $4 \mathrm{a}$ and 4 'a positions.

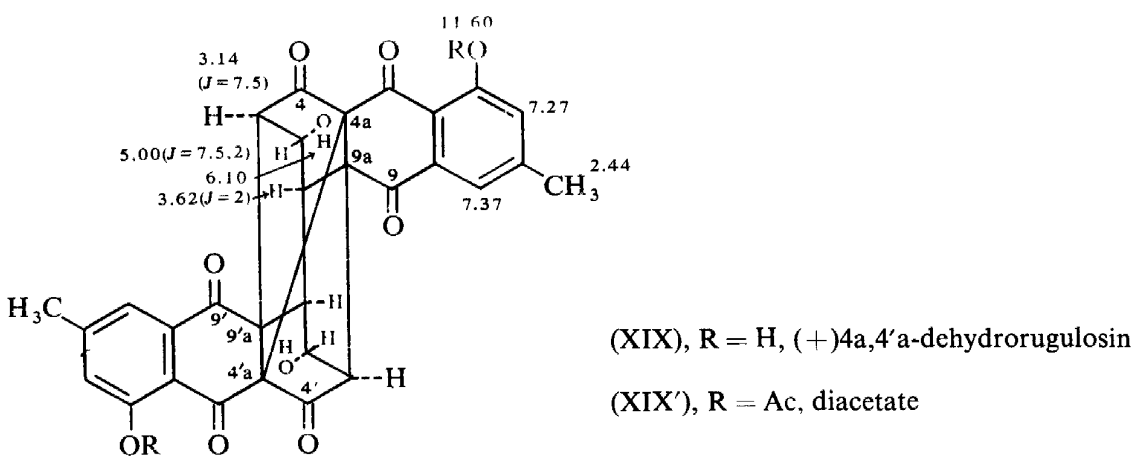

\section{(-)FLAVOSKYRIN}

As elucidated in our earlier study, (-)flavoskyrin, yellow crystals, m.pt $215^{\circ}$ (decomp.), $[\alpha]_{\mathrm{D}}-295^{\circ}$ (dioxan), isolated from Penicillium islandicum Sopp NRRL 1175, was believed to be a monomeric modified anthraquinone which might be half a molecule of rugulosin, since it afforded chrysophanol very easily with dehydration reagents. In reexamining the chemical properties of $(-)$ flavoskyrin, it has been found that on treating it with thionyl chloride and pyridine $(+)$ dianhydrorugulosin is yielded, while on treatment with pyridine $(-)$ rugulosin is afforded. These results may be justified when (-)flavoskyrin is formulated as a dimeric modified anthraquinone, and the mass spectral measurement showed a peak of $M-\mathrm{H}_{2} \mathrm{O}(526)$ to agree with the dimeric molecular formula, $\mathrm{C}_{30} \mathrm{H}_{24} \mathrm{O}_{10}$, for (-)flavoskyrin.

On the other hand, in our earlier studies ${ }^{15}$, we referred to a series of synthetic compounds initially prepared by Zahn and $\mathrm{Koch}^{29}$ as the model compounds for flavoskyrin, luteoskyrin and rubroskyrin.

Starting from 1-hydroxyanthraquinone (XX), catalytic hydrogenation followed by mild oxidation with $\mathrm{Pb}(\mathrm{OAc})_{4}$ resulted in an orange coloured quinonic compound, 3,4-dihydro-1-hydroxyanthraquinone [= 3.4-dihydro, $1,9,10(2 H)$ anthracenetrione] (XXIIa) which was readily converted into a yellowish non-quinonic compound formulated at that time by Zahn and Koch as (XXIII).

We prepared an analogue of the compound (XXIIb) starting from chrysazin (=1,8-dihydroxyanthraquinone) and studied the transformation of this compound and of (XXIla) itself with pyridine into non-quinonic compounds as the model reaction of $(-)$ rubroskyrin being converted into $(-)$ luteoskyrin ${ }^{15}$.

As the monomeric structure of $(-)$ flavoskyrin formerly proposed has become untenable, the model compounds mentioned above have also to be reexamined. 
S. SHIBATA<smiles>[R]c1cccc2c1C(=O)c1c(O)cccc1C2=O</smiles>

$(\mathrm{XX})$
$\mathrm{H}_{2}$<smiles>[R]c1cccc2c(O)c3c(c(O)c12)C(=O)CCC3</smiles><smiles>[R]c1cccc2c1C(=O)C1=C(CCCC1=O)C2=O</smiles>

(XXIIa) $\mathrm{R}=\mathrm{H}$ (XXIIb) $\mathrm{R}=\mathrm{OH}$<smiles>[R]c1cccc2c1C(=O)C1=C(O)CCC=C1C2=O</smiles>

(XXIII)

The mass spectral analyses showed that the non-quinonic compound formulated by Zahn and Koch as (XXIII) and its analogue prepared from chrysazin as well as that derived from chrysophanol (1,8-dihydroxy-3methylanthraquinone) are unequivalent dimers giving $M^{+} 454,486$ and $\frac{1}{2} M+1258$, respectively.

Almost all the u.v. absorption maxima given by the dimer derived from chrysophanol $\left(\lambda_{\max }^{\text {dioxan }} \mathrm{nm}: 270,306,315,330,372,417\right.$ and 434) were also shown, except an absorption at $372 \mathrm{~nm}$, by the intermediate dihydroanthrahydroquinone to suggest that the latter component is involved in the structure of the dimer.

The n.m.r. signal of $\mathrm{C}(9)-\mathrm{OH}$ at $\delta 7.48$ p.p.m. given by the dihydroanthrahydroquinone [(XXI) and its analogues] is not observed in the n.m.r. spectra of the dimeric products. The oxygen atom at C(9), therefore, participates in forming the linkage connecting with the other monomeric moiety. Regarding the results of the n.m.r. and i.r. spectral analyses, the structural formulae (XXIV a, b, c) have been suggested as the most probable ones to represent the dimeric compounds mentioned above ${ }^{30}$.<smiles>[R]C1=CC2(Oc3c4c(c(O)c5c([R])cc([R])cc35)C(=O)CCC4)C(=O)c3c(c([R])cc(O)c32)C(=O)CCC1</smiles>

(XXIVa), $\mathrm{R}=\mathrm{R}^{\prime}=\mathrm{H}$

$(\mathrm{XXIVb}), \mathrm{R}=\mathrm{OH}, \mathrm{R}^{\prime}=\mathrm{H}$

$(X X I V c), \mathrm{R}=\mathrm{OH}, \mathrm{R}^{\prime}=\mathrm{CH}_{3}$ 
With regard to the dimerization reaction of the dihydroanthraquinones and the close similarity between the u.v. absorption spectral curves of the dimerized compound $(\mathrm{XXIVc})$ and $(-)$ flavoskyrin, the latter compound could be formulated as $(\mathrm{XXV})^{31}$.

Table 3. The n.m.r. spectra of (-)flavoskyrin (XXV) and of the compound (XXIVc), $\delta$ (p.p.m.)

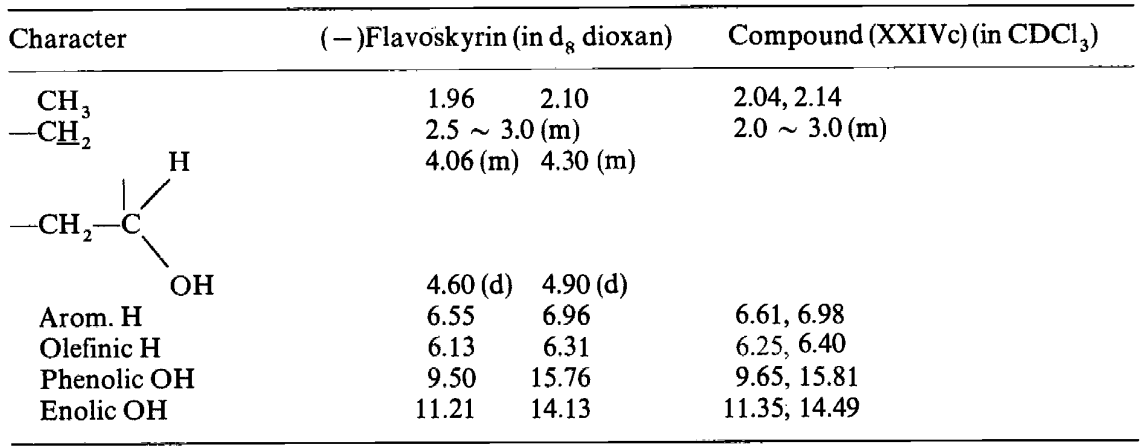

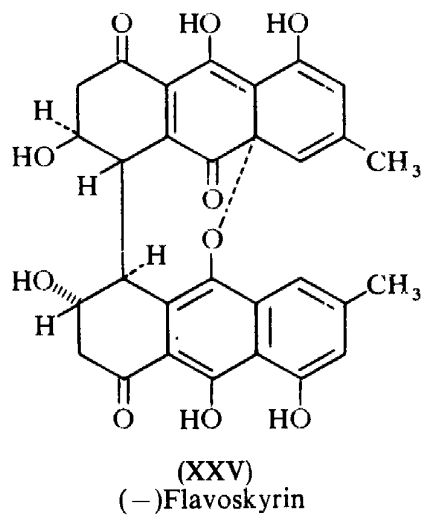

(-)Rugulosin, $\mathrm{C}_{30} \mathrm{H}_{22} \mathrm{O}_{10}$, m.pt $290^{\circ}$ (decomp.), $[\alpha]_{D}-490^{\circ}$, which was obtained from ( - flavoskyrin, has been found as a naturally occurring metabolite from Penicillium islandicum Sopp NRRL 1175 and also from Myrothecium verrcaria (Alb. et Schw.) Ditmer ex Fr. ${ }^{32}$.

\section{OCCURRENCE OF (+)RUGULOSIN AND (+)SKYRIN IN LICHENS}

A few years ago, we isolated $(+)$ skyrin and $(+)$ rugulosin in addition to some known constituents from a very characteristic lichen, Acroscyphus sphaerophoroides Lév. of Sphaerophoraceae occurring as one species in one genus ${ }^{33}$. This lichen grows in very distinct higher altitudes in Asia and South America of the Circumpacific area. Although only a few very small colonies of this lichen have ever been found in Japan, fairly large colonies have been inspected 


\section{S. SHIBATA}

by one of my collaborators, Dr O. Tanaka, when he was in the East Himalaya district as a member of Tokyo University Botanical Expedition, 1967, at Singke-La and Yale-La in Bhutan.

In general, the lichen metabolites are regarded as very unique among natural products with their chemical structures and until recently only a few compounds, such as parietin, emodin, endocrocin, polyporic acid and thelephoric acid, have been known to occur in common lichens and fungi.

When we isolated $(+)$ rugulosin and $(+)$ skyrin from the lichen, it was still regarded as unusual, but very recently skyrin has been found in some other lichens, Trypethliopsis boninensis [Santesson $(1970)^{34}$ ], Physcia obscura var. endococcina, and Pyxine endochrysina [Yosioka et al. $(1971)^{35}$ ]. A colouring matter, entothein, of the lichen, Parmelia entotheiochroa, has been proved to be identical with secalonic acid A (ergochrome AA) a pigment isolated from ergot, the sclerotium of Claviceps purpurea Turasne or from the culture of the fungus ${ }^{36}$. Shortly after that secalonic acids $\mathrm{A}$ and $\mathrm{C}$ (ergochrome $\mathrm{AB}$ ) were isolated from a lichen, Cetraria ornata Müll. Arg. [Yosioka et al. $(1971)^{37}$ ]. The yellow pigments named eumitrins $A_{1}, A_{2}$ and $B$ which were isolated from Usnea bayleyi ${ }^{38}$ have been proved to be the modified bixanthones ${ }^{39}$ which are biogenetically related to the secalonic acids (ergochromes) but are structurally a different type of compound, the details of which will be reported elsewhere.

The occurrence of some fungal metabolites or structurally related compounds in lichens is not now so unusual, and it would not now be so unlikely since most lichen substances are recognized as being metabolites of mycobionts of lichens. The formation of some anthraquinones [Nakano, Komiya and Shibata $\left.(1971)^{40}\right]$, calycin, a diphenylbutadiene derivative [Mosbach $(1967)^{41}$ ] [Nakano, Komiya and Shibata $\left.(1972)^{42}\right],(+)$ usnic acid [Komiya and Shibata $(1969)^{43}$ ] and zeorin, a hopane-type triterpene [Nakano, Komiya and Shibata $\left.(1972)^{42}\right]$, have actually been demonstrated by laboratory cultivations of lichen mycobionts.

The biosynthesis of secalonic acid A, a modified bixanthone, from an anthraquinonoid intermediate has been studied by Franck ${ }^{44}$. The modified bianthraquinones discussed in the present lecture are correlated biogenetically with the modified bixanthones. Biosynthetic experiments on these metabolites are now in progress in our laboratory, details of which will be reported in the near future.

\section{ACKNOWLEDGEMENTS}

I would like to express my warm thanks to my co-workers whose names are mentioned in the individual references below. Their generous efforts, devotion and stimulating ideas have made this work possible.

I am indebted especially to the late Professor $\mathrm{H}$. Raistrick, pioneer of mould chemistry, who kindly consented to help with the work on the colouring matters of Penicillium islandicum and P. rugulosum which were originally started in his laboratory in the London School of Hygiene and Tropical Medicine, and to Professor Y. Asahina, the pioneer of lichen chemistry for his kind advice in lichenology and his interest throughout this work. 
The experiments of $\mathrm{x}$-ray crystallography mentioned in this lecture were guided by Professor Y. Iitaka, and the e.s.r. spectra were measured by Dr Y. Fujita of our Faculty to whom my thanks are due.

\section{REFERENCES}

1 B. H. Howard and H. Raistrick, Biochem. J. 44, 227 (1949): 46, 49 (1950); 56, 56 (1954); 57, 212 (1954).

2 J. Breen, J. C. Dacre, H. Raistrick and G. Smith, Biochem. J. 60, 618 (1955).

3 S. Shibata, Recent Progress in the Chemistry of Natural and Synthetic Colouring Matters and Related Fields, pp 147-166. Academic Press: New York (1962), and references therein.

${ }^{4}$ S. Shibata, Chemistry in Britain, 110-121 (1967), and references cited therein.

5 H. Tsunoda, Jap. J. Nutr. 8, 186 (1951).

${ }^{6}$ M. Miyake, M. Saito, M. Enomoto, T. Shikata, T. Ishiko, K. Uraguchi, F. Sakai, T. Tatsuno, M. Tsukioka and Y. Sakai, Acta Path. Jap. 10, 75 (1960).

7 K. Uraguchi, T. Tatsuno, M. Tsukioka, Y. Sakai, F. Sakai, O. Yonemitsu, H. Ito, M. Miyake, M. Saito, M. Enomoto, T. Shikata and T. Ishiko, Jap. J. Exp. Med. 31, 19 (1961).

${ }^{8}$ K. Sargeant. A. Shedidan, J. O'Kelley and R. B. A. Carnaghan, Nature, London, 192, 1096 (1961).

9 M. C. Lancaster, F. P. Jenckins and J. McL. Philip, Nature, London, 192, 1096 (1961).

10 Y. Ueno, A. Platel and P. Fromageot, Biochem. Biophys. Acta, 134, 27 (1967).

11 Y. Ohba and P. Fromageot, Europ. J. Biochem. 1, 147 (1967); 6, 98 (1968).

12 Y. Ueno, I. Ueno, K. Ito and T. Tatsuno, Experientia, 23, 100 (1967).

13 Y. Ueno and I. Ishikawa, Appl. Microbiol. 406 (1969).

${ }_{14}$ Y. Ueno, I. Ueno, N. Sato, Y. Iitoi, M. Saito, M. Enomoto and H. Tsunoda, Jap. J. Exp. Med. 41, 177 (1971).

15 S. Shibata, T. Murakami and M. Takido, Chem. Pharm. Bull. (Tokyo), 4, 303 (1956).

16 S. Shibata and I. Kitagawa, Chem. Pharm. Bull. (Tokyo), 4, 309 (1956).

17 Y. Ogihara, N. Kobayashi and S. Shibata, Tetrahedron Letters, 1881 (1968).

${ }^{18}$ S. Shibata, Y. Ogihara, N. Kobayashi, S. Seo and I. Kitagawa, Tetrahedron Letters, 3179 (1968).

19 U. Sankawa, S. Seo, N. Kobayashi, Y. Ogihara and S. Shibata, Tetrahedron Letters, 5557 (1968).

20 R. E. Moore and P. J. Scheuer, J. Org. Chem. 31, 3272 (1966).

21 L. H. Piette, M. Okamura, G. P. Rabold, R. T. Ogata, R. E. Moore and P. J. Scheuer, J. Phys. Chem. 71, 29 (1967).

22 S. Shibata, Y. Ogihara, N. Kobayashi and S. Seo, 91st Annu. Meeting Pharm. Soc. Japan (Fukuoka, April, 1971) (Abstracts).

${ }^{23}$ N. Kobayashi, Y. Iitaka, U. Sankawa, Y. Ogihara and S. Shibata, Tetrahedron Letters, 6135 (1968).

${ }^{24}$ N. Kobayashi, Y. Iitaka and S. Shibata, Acta Cryst. B, 26, 188 (1970),

25 S. Shibata and I. Kitagawa, Chem. Pharm. Bull. (Tokyo), 10, 477 (1962).

26 J. D. Bu'Lock and J. R. Smith, J. Chem. Soc. (C), 1941 (1968).

27 S. Seo, U. Sankawa, Y. Ogihara and S. Shibata, Tetrahedron Letters, 767 (1969).

${ }^{28}$ N. Takeda (née Kobayashi), Y. Ogihara and S. Shibata, 92nd Annu. Meeting Pharm. Soc. Japan (Osaka, April, 1972) (Abstracts).

${ }^{29}$ K. Zahn and H. Koch, Ber. Dtsch. Chem. Ges. 71, 172 (1938).

30 S. Seo, U. Sankawa and S. Shibata, Tetrahedron Letters, 731 (1972).

31 S. Seo, Y. Ogihara, U. Sankawa and S. Shibata, Tetrahedron Letters, 735 (1972).

32 S. Minami, private commubication.

33 S. Shibata, O. Tanaka, U. Sankawa, Y. Ogihara, R. Takahashi, S. Seo, D. M. Yang and Y. Iida, Jap. J. Bot. 43, 335 (1968).

${ }^{34}$ J. Santesson, Acta Chem. Scand. 24, 3331 (1970).

35 I. Yosioka, K. Morimoto, K. Murata, H. Yamaguchi and I. Kitagawa, Chem. Pharm. Bull. (Tokyo), 19, 2420 (1971).

36 B. Franck, O. W. Thiele and T. Reschke, Angew. Chem. 73, 494 (1961); Chem. Ber. 95, 1328 (1962).

37 I. Yosioka, K. Murata, K. Morimoto, H. Yamaguchi and I. Kitagawa, Annu. Meeting Japan Soc. Pharmacog. [November 1971 (Shizuoka)]. 


\section{S. SHIBATA}

38 M. Nuno, Jap. J. Bot. 46, 294 (1971).

39 D. M. Yang, N. Takeda (née Kobayashi), U. Sankawa and S. Shibata, 9lst Annu. Meeting Pharm. Soc. Japan [Fukuoka, April (1971)] (Abstracts).

${ }^{40}$ H. Nakano, T. Komiya and S. Shibata, 91 st Annu. Meeting Pharm. Soc. Japan (Fukuoka April, 1971) (Abstracts).

41 K. Mosbach, Acta Chem, Scand. 21, 2331 (1967).

42 H. Nakano, T. Komiya and S. Shibata, 92nd Annu. Meeting Pharm. Soc. Japan [Osaka, (April, 1972)] (Abstracts).

43 T. Komiya and S. Shibata, Chem. Pharm. Bull. (Tokyo), 17, 1305 (1969).

44 B. Franck, Angew. Chem. Internat. Ed. 8, 251-260 (1969), and references cited therein.

\section{NOTE ADDED IN PROOF}

Recent $\mathrm{x}$-ray crystallographic analysis of the compound formulated as (XXIVa) (p 124) in this paper has shown that it must be revised to (XXIV'a). The highest mass peak given by XXIV'a $\left(m / e\right.$ 452) must be $\mathrm{M}^{+}+2$. Accordingly XXIVb and XXIVc might be revised to XXIV'b and XXIV'c, respectively, then (-)flavoskyrin would possibly be represented by $\left(X X X^{\prime}\right)$. All the spectral data and chemical reactions of $(-)$ flavoskyrin are compatible with this formula.<smiles></smiles>

(XXIV'a), $\mathbf{R}=\mathbf{R}^{\prime}=\mathrm{H}^{\prime}$ (XXIV'b), $\mathbf{R}=\mathrm{OH}, \mathrm{R}^{\prime}=\mathrm{H}$ $\left(\mathrm{XXIV}^{\prime} \mathrm{c}\right), \quad=\mathrm{OH}, \mathrm{R}^{\prime}=\mathrm{CH}_{3}$

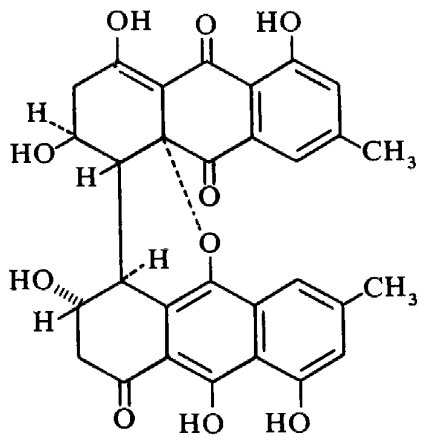

$\left(X X X^{\prime}\right)(-)$ Flavoskyrin 